\title{
Impact of climate change on the water resources of Awash River Basin, Ethiopia
}

\author{
Kinfe Hailemariam* \\ National Meteorological Services Agency, PO Box 1090, Addis A baba, Ethiopia
}

\begin{abstract}
An attempt was made to investigate the sensitivity of water resources to climate change in the Awash River Basin in Ethiopia. The climate of the basin varies from humid subtropical to arid. The basin was divided into 3 subcatchments for better resolution in calibration and simulation. Stationbased meteorological data were processed to obtain areal averages necessary for the simulation. Different sets of temperature and rainfall scenarios were developed using GCM (both transient and $\mathrm{CO}_{2}$ doubling) and incremental scenarios. The IIASA integrated water balance model (WatBal) was used to estimate runoff under a changed climate. The model represents the water balance among surface outflow, subsurface outflow, and evapotranspiration. The model was calibrated using a $10 \mathrm{yr}$ period (1971 to 1980), validated with the next 6 yr period (1981 to 1986), and then applied for different climate scenarios. Results of the impact assessment over the basin showed a projected decrease in runoff, which ranged from -10 to $-34 \%$, with doubling of $\mathrm{CO}_{2}$ and transient scenarios of $\mathrm{CO}_{2}$ increase (GFD3, CCCM, GF01). Sensitivity analysis based on incremental scenarios showed that a drier and warmer climate change scenario results in reduced runoff.
\end{abstract}

KEY WORDS: Awash River Basin · Climate change · General circulation models (GCMs)

\section{INTRODUCTION}

Scientific evidence indicates that due to increased concentration of greenhouse gases in the atmosphere, the climate of the Earth is changing; temperature is increasing and the amount and distribution of rainfall is being altered (Houghton et al. 1996). The IPCC Scientific Assessment suggests that global average temperature may increase between 1.5 and $4.5^{\circ} \mathrm{C}$, with a 'best estimate' of $2.0^{\circ} \mathrm{C}$, in the next century with a doubling of the $\mathrm{CO}_{2}$ concentration in the atmosphere (Houghton et al. 1996).

By affecting certain components of the hydrological cycle, especially precipitation and runoff, a change in climate can alter the spatial and temporal availability of water resources. Climate change that reduces either the overall quantity of water or the timing of when water is available for use will have important effects on agriculture and industrial and urban development.

*E-mail: nmsa@telecom.net.et
Increasing variability alone would enhance the probability of both flood and drought (William 1988). The climatic impact on the water regime may also exacerbate other environmental and social effects of water management. For instance, reduced river runoff can concentrate the effects of pollutants or exacerbate the spread of water-borne disease. Climate fluctuations can also affect the use of agricultural land associated with irrigation systems. Climate change will greatly complicate the design, operation, and management of water-use systems (Gleick \& Shiklomanov 1989). On the other hand, climate change that increases overall water availability could either be beneficial or could increase the risk of flooding. Regions with an arid and semi-arid climate could be sensitive to even insignificant changes in climatic characteristics (Linz et al. 1990). The impact of climate change on water resources is so integrated into different sectors, such as agriculture, health, urbanization, fisheries, and so forth, that it has motivated many to conduct studies using different approaches and come up with a variety of results (Beven 1989, 
McCabe 1990, 1992, Mimikou 1991, Dooge 1992, Kenneth et al. 1994, Niemann et al. 1994).

Therefore, quantitative estimates of hydrologic effects of climate change are essential for understanding and solving the potential water resource management problems associated with water supply for domestic and industrial water use, power generation, and agriculture as well as for future water resource planning, reservoir design and management, and protection of the natural environment.

The objective of this study is to develop a better understanding of the impact of climate change on the water resources of the Awash River Basin in Ethiopia. The Awash River Basin was chosen for the following reasons: (1) it covers a wide climatic zone (from humid subtropical to arid); (2) it is relatively well developed (irrigation, hydroelectric plant) in Ethiopia; (3) several towns, including the capital, Addis Ababa, and industrial enterprises lie within the basin; (4) it has a relatively long-running and dense meteorological and hydrological observation network.

\section{DATA AND METHODOLOGY}

The Awash River starts in the highlands of central Ethiopia, at an altitude of about $3000 \mathrm{~m}$ above sea level. After flowing to the southeast for about $250 \mathrm{~km}$, the river enters the Great Rift Valley at an altitude of $1500 \mathrm{~m}$, and then follows the valley for the rest of its course to Lake Abe on the border with the Djibouti Republic, at an altitude of about $250 \mathrm{~m}$. The total length of the river is about $1200 \mathrm{~km}$ and its catchment area is $113700 \mathrm{~km}^{2}$. The Awash River drains the northerly part of the Rift Valley in Ethiopia from approximately $8.5^{\circ} \mathrm{N}$ to $12^{\circ} \mathrm{N}$ (Fig. 1). The Koka Reservoir, about $75 \mathrm{~km}$ from Addis Ababa, has been in use since 1961 with a net available capacity of $1660 \mathrm{~km}^{2}$ and a concrete dam that is $42 \mathrm{~m}$ high. The maximum rate of outflow through its turbines is $360 \mathrm{~m}^{3} \mathrm{~s}^{-1}$, and the normal annual outflow is about $120000 \mathrm{~m}^{3}$. Losses by evaporation are about $31500 \mathrm{~m}^{3} \mathrm{yr}^{-1}$, and by percolation about $38000 \mathrm{~m}^{3} \mathrm{yr}^{-1}$ (FAO/SF 1964).

The climate of the Awash River Basin varies from humid subtropical over central Ethiopia to arid over the Afar lowlands (Daniel 1977, Lemma 1996).

2.1. Data organization. The Awash River Basin was divided into 3 subcatchments: upper (upstream from Koka Dam station), middle (between Koka and Awash station), and lower (between Awash and Tendaho station) for a better resolution in the calibration and simulation routines. However, the impact assessment was done over the whole of the basin by summing up the 3 subcatchments' discharges into one. Stationbased meteorological data were organized at the sub-

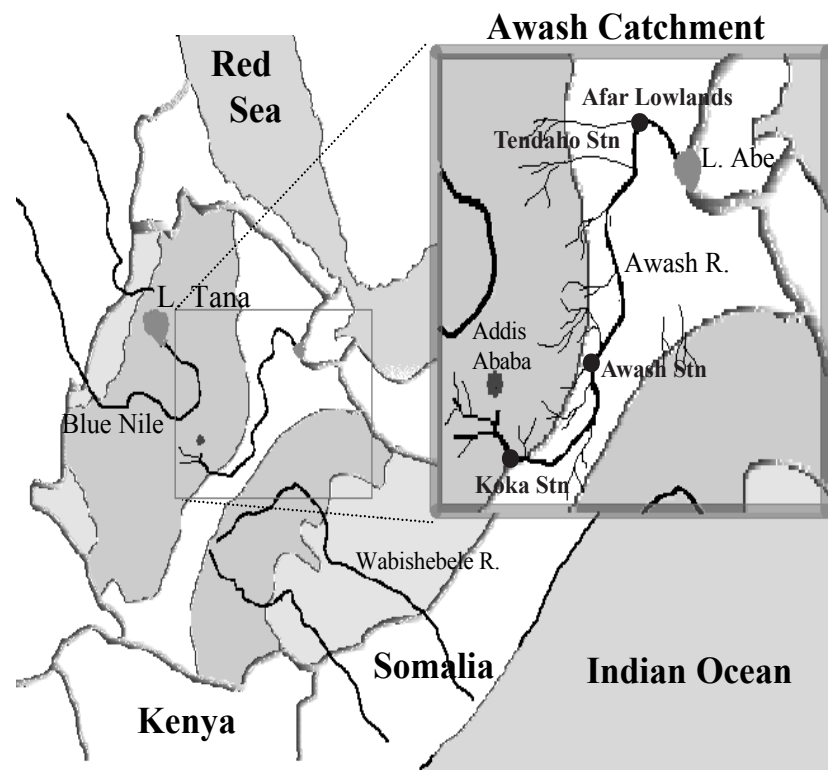

Fig. 1. Location of the Awash River Basin, Ethiopia

basin level for the 3 subcatchments; the inverse distance weighting technique of the grid method GRASS (Solomon \& Cordery 1984) was used to obtain subcatchment average rainfall values for the $12 \mathrm{mo}$ of the year for the period 1971-1990. A simple arithmetic mean was used to derive subcatchment average values for the other meteorological parameters.

Mean monthly temperature and monthly total rainfall from 25 and 61 stations, respectively, within the basin and its vicinity, for the period 1971-1990, as well as temporal averages of relative humidity (15 stations) and sunshine duration (17 stations) obtained from the National Meteorological Services Agency archive were used as the basic meteorological data. For stations with missing data, monthly mean and median values were used for temperature and rainfall, respectively. Observed mean monthly river discharge for 11 subcatchments of Awash River Basin was used as the basic hydrological data (obtained from the Awash Water Development Study, Ministry of Water Resources). Outputs from general circulation models (GCMs) of the Canadian Climate Centre (CCCM) and the Geophysical Fluid Dynamics Laboratory (GFD3), for a doubling of $\mathrm{CO}_{2}$ condition, and from the Geophysical Fluid Dynamics Laboratory (GFDL) models GF01, GF4, and GF7, for a transient increase of $\mathrm{CO}_{2}$, were used for the projection of Awash River runoff in the future.

2.2. C limate change scenarios. Different sets of scenarios were developed to cover the possible range of impacts - incremental and GCM based (both transient and $\mathrm{CO}_{2}$ doubling). In applying the GCM results, the past climatological data have temperature changes added and 
are multiplied by the predicted rainfall ratios to obtain the perturbed climate. In the incremental scenario, a hypothetical increase in temperature $\left(+2\right.$ or $\left.+4^{\circ} \mathrm{C}\right)$ and a change in rainfall $(-20,-10,0,+10$ or $+20 \%)$ are applied. To form a data set of the climate components on a subbasin level, each sub-basin was divided into $1^{\circ} \times 1^{\circ}$ grid points, and the GCM outputs (changes) for the grid center were averaged over the sub-basin.

2.3. Runoff model. The International Institute for Applied Systems Analysis (IIASA) integrated water balance model (WatBal) was used to project runoff under a changed climate $\left(2 \times \mathrm{CO}_{2}\right.$ and transient). The model was calibrated for a certain period of time, validated for another time span, and simulated under changed climate to obtain perturbed runoff so as to see the extent of the climate change impact.

This conceptual model represents the water balance by the use of continuous functions of relative storage to represent surface outflow, subsurface outflow, and evapotranspiration. The groundwater discharge element of the water balance is referred to as subsurface flow, which is a conceptualization of groundwater discharge as a single function. In this approach, the mass balance is represented by a differential equation, and all storage functions are included in a single mass balance. All components of discharge and infiltration are dependent upon the state variables related to the hydrological cycle relative storage, with the exception of baseflow, which is given as a constant in the mass balance equation. The model contains 5 parameters, which are related to baseflow, direct runoff, surface runoff, subsurface runoff, and maximum catchment water holding capacity. Varying time steps can be used depending on the data availability and basin charac- teristics. This approach was implemented using the WatBal software (Niemann et al. 1994, Yates 1994).

WatBal needs to be calibrated and validated with a historical database before it is used to simulate the runoff under different climate scenarios. Therefore, a $16 \mathrm{yr}$ period (1971 to 1986) was used for this purpose based on the availability of hydrological data. The first $10 \mathrm{yr}$ (1971 to 1980) were used for calibration and the remaining $6 \mathrm{yr}$ (1981 to 1986) for validation. Once calibration of the model by identifying optimal values for the 3 parameters is done, the same parameters are applied in the simulation. The 2 parameters baseflow and direct runoff are set to a constant based on the characteristics of the basin.

\section{RESULTS AND DISC USSION}

\subsection{Calibration and validation}

Figs. 2 to 4 show results of the observed versus modeled discharge for the validation and calibration periods for the 3 subcatchments. Table 1 shows the correlation coefficients between modeled and observed discharge with the average error of estimation for the 3 subcatchments, indicating high correlations between observed and estimated data. Table 2 shows the optimum parameters obtained after the model run. Using the calibration parameters in Table 2, the model was employed to forecast runoff under a variety of climate change scenarios to give the anticipated runoff (water supply) under a changed climate. The correlation coefficients and average error values did not show a large difference between the validation and calibration por-

Table 1. Calibration and validation statistics (average error is given in $\mathrm{mm} \mathrm{d}^{-1}$, based on a monthly time step) for the upper, middle and lower Awash River Basin subcatchments

\begin{tabular}{|lcccccr|} 
& \multicolumn{2}{c}{ Upper } & \multicolumn{2}{c|}{ Middle } & \multicolumn{2}{c|}{ Lower } \\
& Correlation & Avg. error & Correlation & Avg. error & \multicolumn{2}{c}{ Correlation Avg. error } \\
\hline Calibration & 0.96 & 0.10 & 0.86 & 0.06 & 0.88 & 0.05 \\
Validation & 0.93 & 0.12 & 0.72 & 0.14 & 0.92 & 0.05 \\
\hline
\end{tabular}

Table 2. Parameters used in simulating the WatBal model for the 3 Awash River Basin subcatchments. GC: ground cover index; Zi: initial storage state; CF: Priestly Taylor coefficient; DRC: direct runoff coefficient; Lt: latitude

\begin{tabular}{|lccccccccc|}
\hline & $\begin{array}{c}\text { Maximum } \\
\text { catchment water } \\
\text { holding capacity }\end{array}$ & $\begin{array}{c}\text { Surface } \\
\text { runoff }\end{array}$ & $\begin{array}{c}\text { Subsurface } \\
\text { runoff }\end{array}$ & GC & Zi & CF & Baseflow & DRC & Lt \\
\hline Upper & 232.5 & 8 & 0.12 & 0.5 & 0.1 & 1.26 & 0.03 & 0.03 & 8.5 \\
Middle & 262 & 6.88 & 0.86 & 0.5 & 0.1 & 1.65 & 0.09 & 0.0 & 8.5 \\
Lower & 235.5 & 3.73 & 0.69 & 0.9 & 0.1 & 1.74 & 0.02 & 0.0 & 10.4 \\
\hline
\end{tabular}




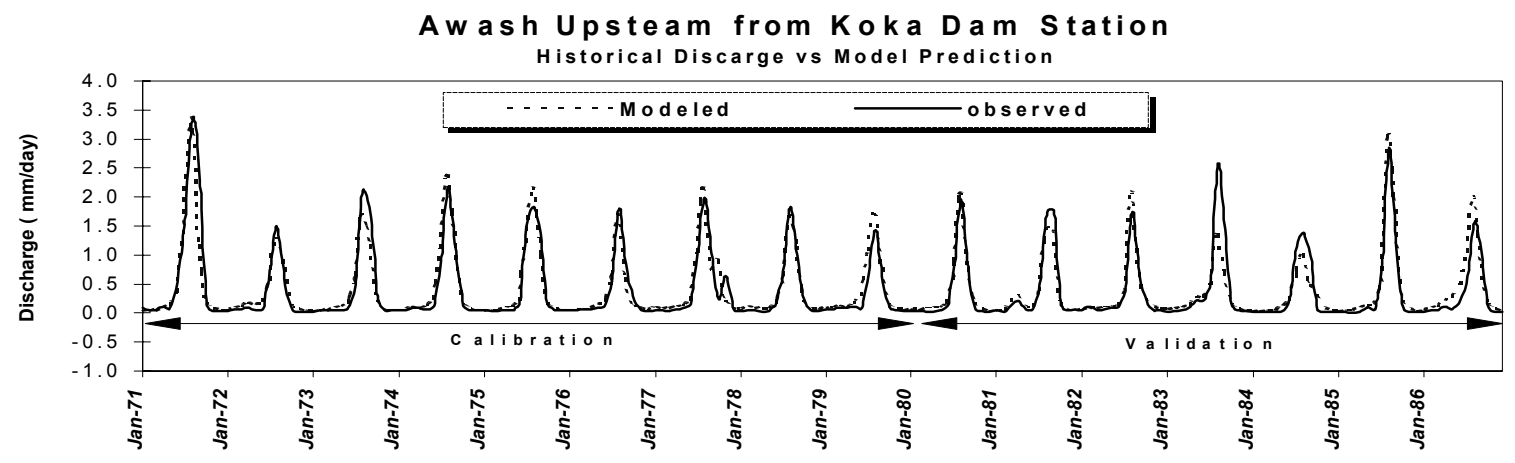

Fig. 2. Upper Awash River Basin: historical versus modeled monthly discharge

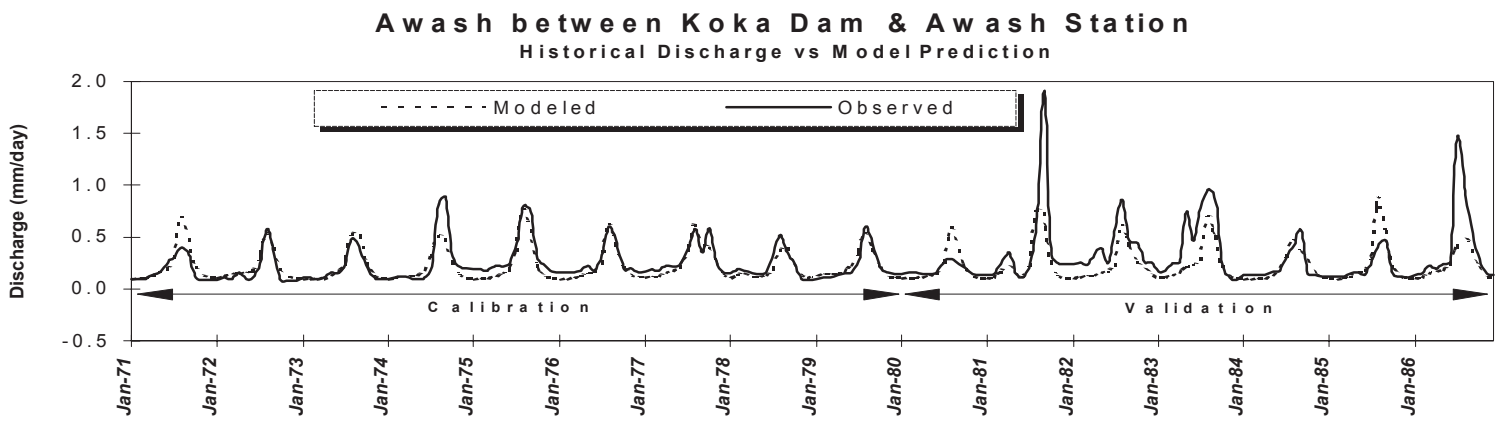

Fig. 3. Middle Awash River Basin: historical versus modeled monthly discharge

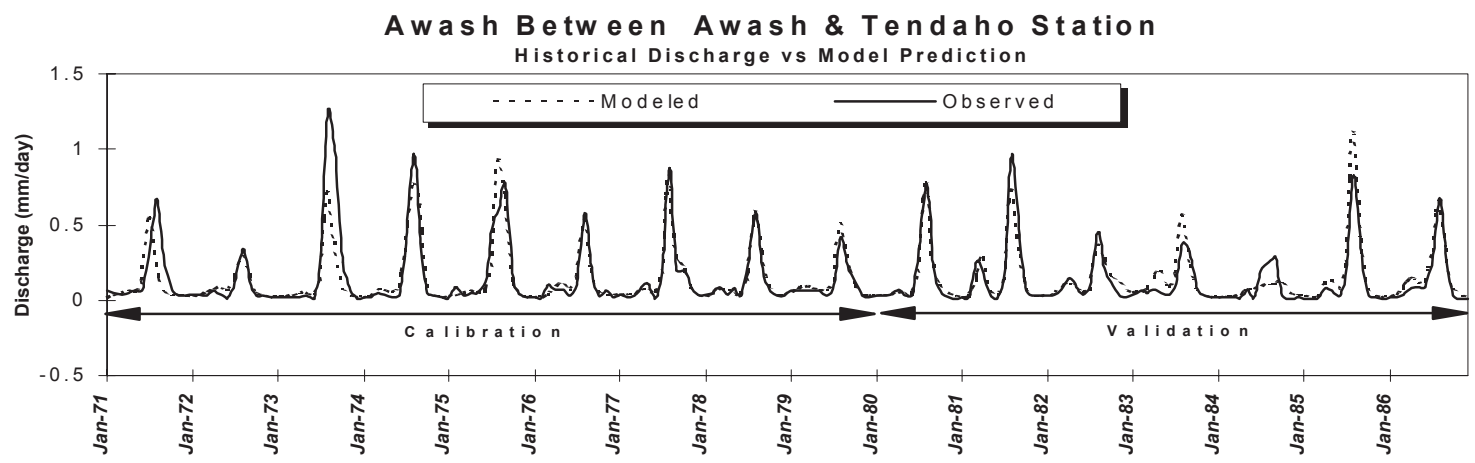

Fig. 4. Lower Awash River Basin: historical versus modeled monthly discharge

tions of the time series, except for the middle Awash River Basin subcatchment, which may result from some extremely high flows in the validation time series. Thus, the model performance is assessed to be sufficient for assessing the range of uncertainty and scale of climate change.

\subsection{Water supply changes based on prescribed scenarios}

Table 3 shows the effect of the prescribed climate change scenarios - that is, uniform temperature and precipitation adjustments-on water supply (annual runoff). It shows the anticipated changes in runoff (supply) compared with the present-day runoff. According to the results over the whole basin, runoff decreases significantly in warmer and drier scenarios. A $20 \%$ decrease in rainfall coupled with a $2^{\circ} \mathrm{C}$ increase in temperature would result in a $41 \%$ decrease in the annual runoff. Even a temperature increase of $2^{\circ} \mathrm{C}$ without precipitation change would result in a $9 \%$ decrease in annual runoff. On the other hand, an increase of precipitation by $10 \%$ would offset a 2 to $4^{\circ} \mathrm{C}$ increase in temperature and result in a surplus of runoff ranging from 4 to $12 \%$. 
Table 3. Anticipated percentage change in runoff over the whole Awash River Basin based on prescribed climate change compared with the present-day runoff

\begin{tabular}{|clllll|}
\hline Temperature $\left({ }^{\circ} \mathrm{C}\right)$ & \multicolumn{5}{c|}{ Precipitation (\%) } \\
\hline & -20 & -10 & +0 & +10 & +20 \\
+2 & -41 & -25 & -9 & +12 & +33 \\
+4 & -43 & -30 & -15 & +4 & +23 \\
\hline
\end{tabular}

Table 4. Projected percentage change in runoff over the whole Awash River Basin based on GCM prediction of temperature and rainfall for a doubling of $\mathrm{CO}_{2}$ and a transient period compared with the present-day runoff

\begin{tabular}{|cccccc|}
\hline & \multicolumn{2}{c}{ Doubling of $\mathrm{CO}_{2}$} & \multicolumn{3}{c|}{ Transient } \\
CCCM & GFD3 & GF4 & GF7 & GF01 \\
& $(2075)$ & $(2075)$ & $(2010)$ & $(2040)$ & $(2070)$ \\
\hline Runoff change (\%) & -33 & -10 & -25 & -34 & -27 \\
\hline
\end{tabular}

\subsection{Water supply changes based on G C M}

Over the Awash River Basin, a temperature increase of 2.4 and $3.0^{\circ} \mathrm{C}$, respectively, is projected by the CCCM and GFD3 models for a doubling of $\mathrm{CO}_{2}$. GFD3 shows a $5 \%$ increase in precipitation, while CCCM indicates a $2 \%$ decrease with doubling of $\mathrm{CO}_{2}$. Table 4 shows the results of the GCM scenarios for change in runoff: CCCM, GFD3, GF4, GF7, and GF01 all show a decrease in runoff ranging from 10 to $34 \%$. Therefore, the Awash River Basin would be significantly affected by the changed climate; that is, a considerable water deficit is projected. All models suggested that global warming would result in a general increase in dryness, which would decrease water availability.

\section{CONCLUSION}

From this impact assessment study, it can be concluded that the general warming simulated by all GCM s under $\mathrm{CO}_{2}$ doubling would result in a substantial decrease in annual runoff over the Awash River Basin. Modeled runoff ranges from -10 to $-34 \%$ relative to observed runoff. Sensitivity analysis based on incremental scenarios showed that a drier and warmer climate change scenario results in reduced runoff. Areas where precipitation does not increase sufficiently to offset the temperature increase will have significant risk of drought.

Results of climate change assessment are highly dependent on the input data and uncertainty of the models. Thus, further study in the area with updated data and a variety of models is required. In addition, possible adaptation options to the impacts on the basin must also be studied. A complete study should also take into consideration integrating other factors such as anticipated developments in agriculture and industry and population growth in the basin, and the parallel impacts of climate in these sectors.

Acknowledgements. This work was part of the US-DOE sponsored Climate Change Country Studies Program. Support from the program is gratefully acknowledged. I am grateful to the National Meteorological Services Agengy for giving me the opportunity to participate in the program. Thanks are also due Mr Tamiru Worku, Mr Abede Tadege and Mr Ademe Mekonnen for their comments and encouragement.

\section{LITERATURE CITED}

Beven K (1989) Changing ideas in hydrology - the case of physically-based models. J Hydrol 105:157-172

Daniel G (1977) Aspects of climate and water budget in Ethiopia, Technical monograph, Addis Ababa University Press, Addis Ababa

Dooge J Cl (1992) Hydrologic models and climate change. J Geophys Res 97(D3):2677-2686

FAO/SF (1964) Report on survey of Awash River Basin. (Imperial Ethiopia government United Nations Special fund project). General report, FAO/SF:10/ETH, FAO, Rome

Gleick P, Shiklomanov IA (1989) The impact of climate change for water resources. Second meeting of IPCC WG-2, WMO/UNEP, Geneva

Houghton J T, Meira Filho LG, Callander BA, Harris N, Kattenberg A, M askell K (1996) Climate change 1995: the science of climate change. Contribution of WGI to the second assessment report of the Intergovernmental Panel on Climate Change. Cambridge University Press, Cambridge

Kenneth MS, Chibo OS, Magdy S, David NY (1994) An assessment of integrated climate change impacts on Egypt. IIASA Working Paper WP-94-48, IIASA, Laxenburg

Lemma G (1996) Climate classification of Ethiopia. M eteorological Research Report Series No. 3, National Meteorological Services Agency of Ethiopia, Addis Ababa

Linz H, Shiklomanov I, Mostefakara K (1990) Chapter 4, Hydrology and water. In: Likely impact of climate change. IPCC WGII report, WMO/UNEP, Geneva

McCabe GJ J r, Ayers M A (1990) Hydrologic effects of climate change in the Delaware River Basin. Water Resources Bulletin, No. 89067:1231-1242, US Geological Survey, West Trenton, NJ

McCabe GJ J r, David MW (1992) Effects of climate change and climate variability on the Thornthwaite moisture index in the Delaware River Basin. US Geological Survey, West Trenton, NJ

Mimikou MA, Kouvopoulos YS (1991) Regional climate change impact: impact on water resources. National Technical University of Athens, Department of Civil Engineering Division of Water Resources, Hydraulic and Maritime Engineering, Athens

Niemann J , Strzepek K, Yates D (1994) Impacts of spatial \& temporal data on climate change assessment of Blue Nile runoff. IIASA Working Paper WP-94-44, IIASA, Laxenburg 
Solomon SI, Cordery I (1984) Compendium of meteorology for Class I and Class II meteorological personnel, Vol II, Part 5. Hydrometeorology, WMO - No. 364, Geneva

William ER (1988) Assessing the social implication of climate fluctuations, a guide to climate impact studies. Depart- ment of Geography and National Hazards Center, University of Colorado Boulder

Yates D (1994) WatBal - an integrated water balance model for climate impact assessment for river runoff. IIASA Working Paper WP-94-64, IIASA, Laxenburg 